\title{
Effects of Clofibrate with Androsterone (Atromid) and without Androsterone (Atromid-S) on Blood Platelets and Lipids in Ischæmic Heart Disease
}

\author{
PETER CARSON, LAWSON MCDONALD, SOL PICKARD, THOMAS PILKINGTON, \\ BETH DAVIES, AND FIONA LOVE
}

From the Institute of Cardiology, National Heart Hospital, London W.1, and St. George's Hospital, London S.W.1

A mixture of androsterone and clofibrate (atromid) lowers the blood cholesterol and triglycerides (Oliver, 1962). Clofibrate without androsterone (atromid-S) appears to have the same effect on the serum lipids (Oliver, 1963; Hellman et al., 1963). Atromid lowers platelet stickiness (Carson et al., 1963a, b) which is increased in patients with ischæmic heart disease (McDonald and Edgill, 1957); the effects of atromid and atromid-S on platelet stickiness have now been compared, and the findings, reported below, are related to changes in the blood lipids.

\section{SUBJECTS AND METHODS}

Studies were made on 35 men, with ischæmic heart disease, aged between 43 and 68 years (average 55). All had angina pectoris on effort, or had experienced past cardiac infarction. In none had cardiac infarction occurred within four months of the start of the study. No patient had heart failure or coronary insufficiency, and none was receiving anticoagulant treatment. Of the 35 patients, 18 received $2 \mathrm{~g}$. atromid daily for 2 months, in divided dosage, and were then observed for a further 2 months: 8 of these were subsequently given atromid-S $2 \mathrm{~g}$. daily for 2 months, and were further observed for another period of 2 months. The remaining 17 patients received atromid-S $2 \mathrm{~g}$. a daily for 2 months, and were under investigation for a further 2 months after the drug was stopped.

Platelet stickiness (Wright, 1941; McDonald and Edgill, 1957, 1958), serum cholesterol, and serum low density lipoprotein cholesterol (Abell et al., 1952), low density serum lipoprotein and its $S_{f}, 12$ and 12400 fractions (Lindgren and Gofman, 1957), were determined in venous blood on 3 separate occasions before treatment was started, and then thrice at monthly intervals. Platelet stickiness is expressed as the percentage of platelets remaining at 20 minutes. Brecher and Cronkite's (1950) method of platelet counting was

Received October 16, 1965. used in the platelet stickiness test, but a hæmocytometer pipette for white cells, instead of one for red cells, was used.

\section{RESULTS}

In Fig. 1, the mean values of platelet stickiness and serum lipids are shown before, during, and after treatment with atromid and atromid-S. In Fig. 2, the changes in the second group treated with atromid-S alone are shown.

Platelet Stickiness. Table I shows the mean values of platelet stickiness before, during, and after treatment with atromid in 18 patients, and subsequent treatment with atromid-S in 8 of them. After one month on atromid abnormal platelet stickiness changed to over 70 per cent in all except 4 patients. After a further month, the platelet stickiness in 3 of these patients was over 70 per cent. The 8 patients treated with atromid-S after treatment with atromid showed a much smaller change during treatment with atromid-S.

Table II shows the mean values of platelet stickiness before, during, and after treatment with atromid-S. Statistical analysis of these results indicates that both atromid and atromid-S significantly decreased platelet stickiness $(p<0.001)$, but Fig. 1 and 2 show that a greater change occurred with atromid. The mean value for the group on atromid was 65 per cent before treatment and 75 per cent after two months of treatment, whereas the initial value in the group given atromid-S was 64 per cent and after two months of treatment it was 67 per cent. In the group given atromid-S, though in 15 the change in platelet stickiness was in a favourable direction, after one month only 3 patients had platelet stickiness over 70 per cent, and after two months only 5 . 

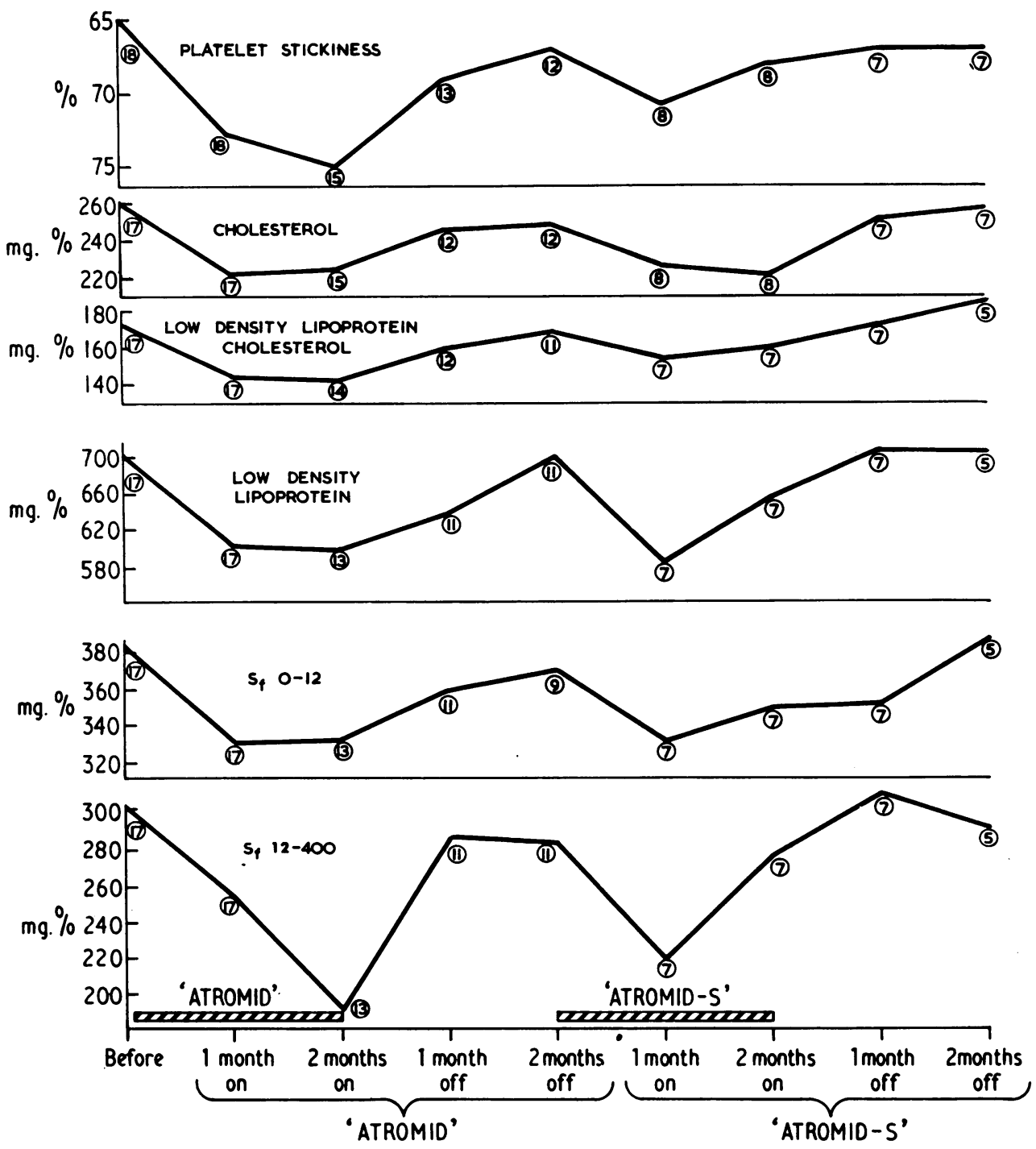

Figures in circles indicate number of patients tested

Fig. 1.-Mean values for platelet stickiness (\% remaining at $20 \mathrm{~min}$.), cholesterol, low density lipoprotein cholesterol, low density lipoprotein, $S_{f} 0-12$ lipoprotein, and $S_{f} 12-400$ lipoprotein in patients receiving atromid and atromid-S.

Cholesterol. All patients treated with atromid and all except 3 who were treated with atromid-S, showed a fall in serum cholesterol. The mean fall on atromid at one month was $38 \mathrm{mg} . / 100 \mathrm{ml}$., and for atromid-S $43 \mathrm{mg} . / 100 \mathrm{ml}$. This change was largely but not exclusively due to a fall in low density lipoprotein cholesterol. The changes with both drugs were statistically significant $(p<0.001)$.

Low Density Lipoproteins. The total low density lipoprotein and its two $S_{f}$ fractions showed group falls; but after one month 5 patients on atromid and 3 on atromid-S had an increase in total low density lipoprotein. The changes in the two $S_{f}$ fractions were also much less uniform than those in serum cholesterol.

\section{Discussion}

These results show that both atromid and atromid-S have a significant effect on platelet stickiness in male patients with ischæmic heart 
TABLE I

PLATELET STICKINESS (MEAN VALUES) OF INDIVIDUAL PATIENTS BEFORE, DURING, AND AFTER TREATMENT WITH ATROMID, AND SUBSEQUENT TREATMENT WITH ATROMID-S IN 8 PATIENTS

\begin{tabular}{|c|c|c|c|c|c|c|c|c|c|}
\hline Patient & $\begin{array}{c}\text { Before } \\
\text { treatment }\end{array}$ & 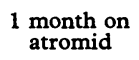 & 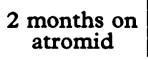 & 1 month off & $\begin{array}{l}2 \text { months off } \\
\text { atromid }\end{array}$ & $\begin{array}{l}1 \text { month on } \\
\text { atromid-s }\end{array}$ & $\begin{array}{l}2 \text { months on } \\
\text { atromid-S }\end{array}$ & 1 month off & $\begin{array}{l}2 \text { months off } \\
\text { atromid-s }\end{array}$ \\
\hline $\begin{array}{r}1 \\
2 \\
3 \\
4 \\
5 \\
6 \\
7 \\
8 \\
9 \\
10 \\
11 \\
12 \\
13 \\
14 \\
15 \\
16 \\
17 \\
18\end{array}$ & $\begin{array}{l}71 \\
63 \\
60 \\
65 \\
66 \\
66 \\
63 \\
65 \\
66 \\
66 \\
65 \\
62 \\
65 \\
62 \\
69 \\
67 \\
62 \\
71\end{array}$ & $\begin{array}{l}81 \\
71 \\
69 \\
68 \\
72 \\
74 \\
64 \\
74 \\
73 \\
70 \\
65 \\
71 \\
73 \\
77 \\
85 \\
78 \\
71 \\
80\end{array}$ & $\begin{array}{l}82 \\
74 \\
70 \\
74 \\
77 \\
75 \\
74 \\
75 \\
76 \\
77 \\
72 \\
72 \\
82 \\
72 \\
79\end{array}$ & $\begin{array}{l}\overline{73} \\
66 \\
73 \\
68 \\
74 \\
64 \\
72 \\
\frac{71}{64} \\
71 \\
\frac{1}{68} \\
\frac{68}{67} \\
68\end{array}$ & $\begin{array}{l}69 \\
71 \\
64 \\
77 \\
65 \\
72 \\
68 \\
\frac{56}{61} \\
\frac{61}{64} \\
\frac{-}{二} \\
66 \\
70\end{array}$ & $\begin{array}{l}65 \\
75 \\
68 \\
74 \\
64 \\
76 \\
69 \\
75\end{array}$ & $\begin{array}{l}71 \\
62 \\
69 \\
67 \\
75 \\
73 \\
64 \\
64\end{array}$ & $\begin{array}{l}77 \\
64 \\
63 \\
65 \\
65 \\
71 \\
64\end{array}$ & $\begin{array}{l}72 \\
64 \\
62 \\
68 \\
62 \\
76 \\
66\end{array}$ \\
\hline
\end{tabular}

TABLE II

PLATELET STICKINESS (MEAN VALUES) OF INDIVIDUAL PATIENTS BEFORE, DURING, AND AFTER TREATMENT WITH ATROMID-S

\begin{tabular}{|c|c|c|c|c|c|c|}
\hline Patient & & Before treatment & $\begin{array}{l}1 \text { month on } \\
\text { atromid-S }\end{array}$ & $\begin{array}{l}2 \text { months on } \\
\text { atromid-S }\end{array}$ & $\begin{array}{l}1 \text { month off } \\
\text { atromid-S }\end{array}$ & $\begin{array}{l}2 \text { months of } \\
\text { atromid-S }\end{array}$ \\
\hline $\begin{array}{r}1 \\
2 \\
3 \\
4 \\
5 \\
6 \\
7 \\
8 \\
9 \\
10 \\
11 \\
12 \\
13 \\
14 \\
15 \\
16 \\
17\end{array}$ & - & $\begin{array}{l}63 \\
60 \\
58 \\
70 \\
60 \\
60 \\
67 \\
64 \\
62 \\
74 \\
65 \\
65 \\
59 \\
65 \\
66 \\
65 \\
61\end{array}$ & $\begin{array}{l}63 \\
66 \\
63 \\
77 \\
56 \\
62 \\
68 \\
67 \\
66 \\
82 \\
66 \\
67 \\
65 \\
68 \\
71 \\
68 \\
64\end{array}$ & $\begin{array}{l}68 \\
69 \\
68 \\
76 \\
52 \\
67 \\
70 \\
61 \\
69 \\
78 \\
68 \\
61 \\
62 \\
65 \\
73 \\
73 \\
63\end{array}$ & $\begin{array}{l}68 \\
68 \\
60 \\
66 \\
51 \\
71 \\
72 \\
69 \\
69 \\
67 \\
69 \\
58 \\
68 \\
71 \\
66 \\
65\end{array}$ & $\begin{array}{l}59 \\
66 \\
58 \\
68 \\
50 \\
68 \\
67 \\
63 \\
66 \\
64 \\
70 \\
59 \\
66 \\
75 \\
67 \\
63\end{array}$ \\
\hline
\end{tabular}

disease, though with atromid-S the effect appears to be less. Gilbert and Mustard (1963) described the effects of atromid on platelet economy which may be regarded as similar to those in the present study. However, these results are different from those of Symons, de Toszeghi, and Cook (1964) who found an equal effect with both drugs on platelet stickiness in 6 patients; these were receiving anticoagulant treatment which may have affected their findings. The changes brought about by atromid and atromid-S are potentially antithrombotic, as are other methods that are known to affect platelet stickiness favourably (McDonald, 1962). However the present study provides no evidence that either atromid or atromid-S favourably affects the morbidity or mortality of ischæmic heart disease. Only extensive clinical trials can settle these questions. Both atromid and atromid-S produced similar changes in the lipid pattern, and atromid-S may act by potentiating the effects of endogenous androsterone (Thorp, 1962).

Statistical analysis revealed no close correlation between the changes in platelet stickiness and those in the lipids, with both atromid and atromid-S; the lipid changes and platelet changes appear to be independent. With atromid, platelet stickiness and the blood lipids did not return to their initial level one month after treatment was stopped; the difference between the mean levels one month after stopping atromid and the initial levels was significant $(p<0.005)$, though this was not found with atromid-S $(p>0.05)$. Thus there is the possibility that intermittent therapy with atromid might be as effective as continuous treatment.

\section{SUMMARY}

The effects of clofibrate with and without androsterone on platelet stickiness and the blood 

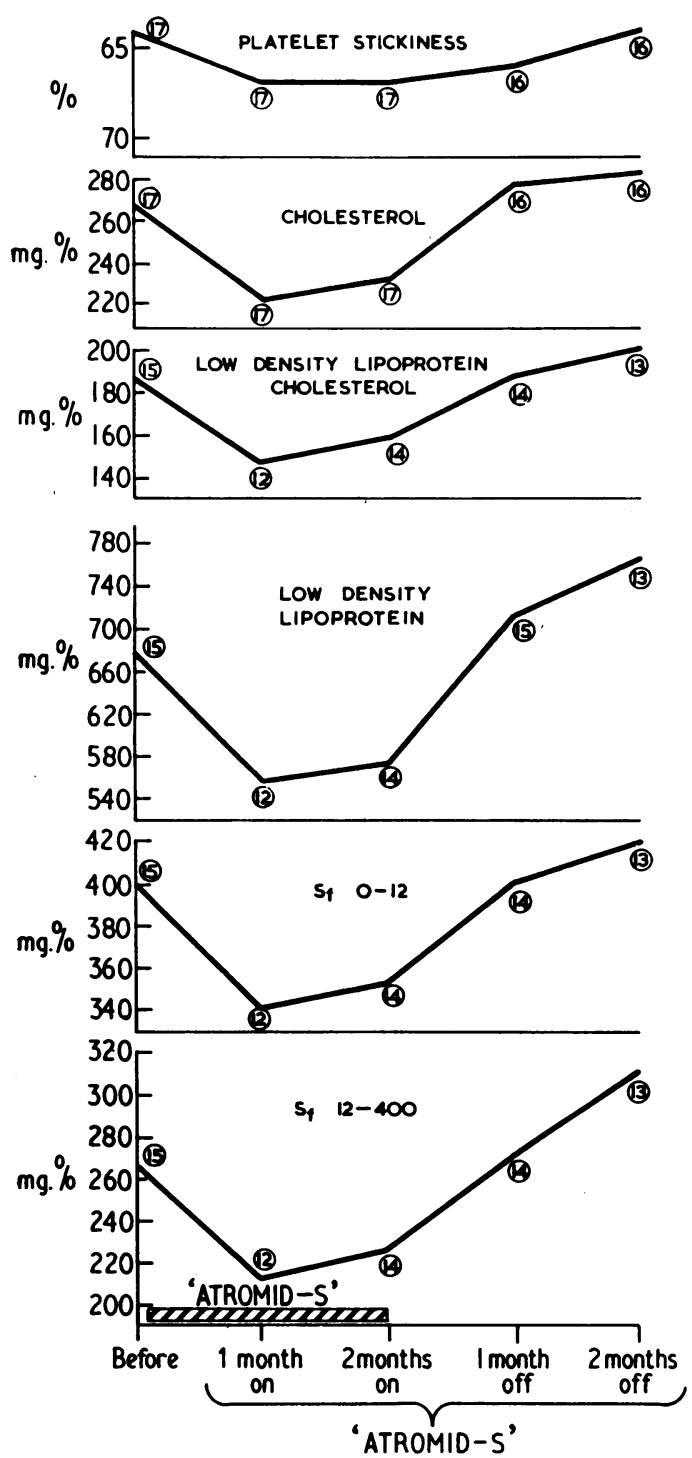

Figures in circles indicate number of patients tested

FIG. 2.-Mean values for platelet stickiness (\% remaining at $20 \mathrm{~min}$.), cholesterol, low density lipoprotein cholesterol, low density lipoprotein, $S_{f}$ 0-12 lipoprotein, and $S_{f} 12-$ 400 lipoprotein in patients receiving atromid-S.

lipids have been studied in 35 men with ischæmic heart disease.

Both drugs favourably decreased platelet stickiness $(p<0.001)$, but the effect with clofibrate and androsterone (atromid) was more marked than with clofibrate alone (atromid-S). Both drugs produced a statistically significant $(p<0.001)$ and similar fall in serum cholesterol; their effects on low density lipoprotein were inconstant. The changes in platelet stickiness and in the lipids appeared to be independent.

We thank the physicians of the National Heart Hospital who allowed us to study their patients; Professor Peter Armitage and Mrs. Wendy Fox of the London School of Hygiene and Tropical Medicine, for the statistical analysis; the British Heart Foundation and Imperial Chemical Industries Ltd. for grants that covered part of this investigation; and Imperial Chemical Industries Ltd. for supplying the atromid and atromid-S.

\section{REFERENCES}

Abell, L. L., Levy, B. B., Brodie, B. B., and Kendall, F. E. (1952). A simplified method for the estimation of total cholesterol in serum and demonstration of its specificity. f. biol. Chem., 195, 357.

Brecher, G., and Cronkite, E. P. (1950). Morphology and enumeration of human blood platelets. $\mathcal{f}$. appl. Physiol., 3, 365.

Carson, P., McDonald, L., Pickard, S., Pilkington, T., Davies, B., and Love, F. (1963a). Effects of Atromid on platelet stickiness. F. Atheroscler. Res., 3, 619.

-, Pickard, S., Pilkington, T., and McDonald, L. (1963b). Effects of an androsterone compound in ischæmic heart disease. In Proceedings of the British Cardiac Society. Brit. Heart F., 25, 693.

Gilbert, J. B., and Mustard, J. F. (1963). Some effects of Atromid on platelet economy and blood coagulation in man. F. Atheroscler. Res., 3, 623.

Hellman, L., Zumoff, B., Kessler, G., Kara, E., Rubin, I. L., and Rosenfeld, R. S. (1963). Reduction of serum cholesterol and lipids by ethyl chlorophenoxyisobutyrate. F. Atheroscler. Res., 3, 454.

Lindgren, F. T., and Gofman, J. W. (1957). The role of lipoproteins in coronary disease. Bull. schweiz. Akad. med. Wiss., 13, 152.

McDonald L. (1962). Studies on blood coagulation and thrombosis ana on the action of heparin in ischemic heart disease. Amer. F. Cardiol., 9, 365.

- , and Edgill, M. (1957). Coagulability of the blood in ischæmic heart-disease. Lancet, 2, 457.

$\longrightarrow$, and - (1958). Dietary restriction and coagulability of the blood in ischæmic heart-disease. Lancet, $1,996$.

Oliver, M. F. (1962). Reduction of serum-lipid and uricacid levels by an orally active androsterone. Lancet, 1 , 1321.

- (1963). Further observations on the effects of Atromid and of ethyl chlorophenoxyisobutyrate on serum lipid levels. F. Atheroscler. Res., 3, 427.

Symons, C., de Toszeghi, A., and Cook, I. J. Y. (1964). Effect of ethyl chlorophenoxyisobutyrate with or without androsterone on platelet stickiness. Lancet, 2, 233.

Thorp, J. M. (1962). Experimental evaluation of an orally active combination of androsterone with ethyl chlorophenoxyisobutyrate. Lancet, 1, 1323.

Wright, H. P. (1941). The adhesiveness of blood platelets in normal subjects with varying concentrations of anticoagulants. F. Path. Bact., 53, 255. 